\title{
Xenoliths from the harzburgite source of Kimberley diamonds: constraints on craton root and diamond formation
}

\author{
David R. Bell and Peter R. Buseck \\ School of Earth and Space Exploration, Arizona State University, Tempe 85287-1404, USA.
}

\section{Introduction}

Subcalcic garnet xenocrysts, diamond inclusions, and rare peridotite xenoliths indicate the ubiquitous but volumetrically minor presence of highly refractory lithologies in Archean subcontinental mantle. Despite their subordinate contribution to Archean subcontinental mantle roots, these ultra-depleted harzburgites host a major fraction of lithospheric diamonds. It remains to be established with any certainty why diamonds are preferentially associated with these lithologies. In addition to their significance as diamond host lithologies, the subcalcic harzburgites play an important role in constraining models of craton root petrogenesis. Experimental studies suggest that the $\mathrm{Cr} / \mathrm{Al}$ ratios necessary to stabilize knorringite-rich garnets in peridotite can only be attaind by melt depletion within the stability field of spinel, which occurs at $<3 \mathrm{GPa}$ for undepleted mantle compositions. The compositions of minerals in these peridotites have therefore been used to constrain melting to shallow mantle depths, supporting models of craton root assembly by lateral accretion processes.

\section{Petrographic characteristics}

A collection of largely clinopyroxene-free peridotites from the Boshof Road Dump (Bultfontein diamond mine) at Kimberley, South Africa, reveals that the rocks hosting subcalcic garnet compositions (Fig. 1) are orthopyroxene-poor harzburgites and dunites with minor proportions of accessory garnet and chromite and occasional phlogopite and diamond. Similar olivine-rich xenoliths without garnet, but containing coarse Cr-rich spinel, and in one case diamond, are considered cofacial. The xenoliths are characterized by a pale yellow color on weathered surfaces, sparse lilac garnets up to $\sim 1 \mathrm{~cm}$ diameter, and coarse grained chromite visible to the naked eye. Coarse-grained phlogopite up to $1 \mathrm{~cm}$ occurs in some samples. Unlike Siberian counterparts (Pokhilenko et al. 1993), the olivine in the dunitic xenoliths is not unusually coarse-grained, but may attain grain sizes up to $\sim 1.5 \mathrm{~cm}$.

The orthopyroxene-poor xenoliths are generally distinct from other garnet-bearing harzburgite xenoliths, some of which contain mildly subcalcic garnets (Fig. 1). These include coarse grained harzburgites with uniformly distributed garnet as well as „,cluster garnet harzburgites“ in which large clotted intergrowths of garnet, orthopyroxene and occasional phlogopite are dispersed in a uniform, olivineorthopyroxene matrix typically rich in orthopyroxene. Little compositional or textural overlap between the two groups of harzburgites is apparent, and their origins are likely distinct.

\section{Mineral compositions}

Garnets from orthopyroxene-rich harzburgites overlap those from garnet lhrzolites, with some devating to Ca-poor compositons. Olivine compositions in the orthopyroxene-poor harzburgites are highly magnesian, ranging from Fo93.3 to Fo95.6, with a mean $(n=24)$ of Fo94.2. Enstatites are similarly magnesian (En94.3 - En96.3), with $\mathrm{Al}_{2} \mathrm{O}_{3}=0.54$ to 0.84 wt. $\%$ and $\mathrm{Cr}_{2} \mathrm{O}_{3}=0.35$ to 0.53 wt. \%). Spinels average 61.7 wt. $\% \mathrm{Cr}_{2} \mathrm{O}_{3}(59.6-63.6 \%)$ and contain up to 0.7 wt. $\% \mathrm{TiO}_{2}$ which is negatively correlated with the $\mathrm{Cr}$ content. Garnet compositions (Fig. 1) show $\mathrm{Cr}_{2} \mathrm{O}_{3}$ contents between 5.5 and 11 wt. \%, positively correlated with $\mathrm{CaO}$ contents of $2.0-8.1$ wt. $\% \mathrm{CaO}$. Phlogopite contains up to $0.6 \mathrm{wt} \% \mathrm{Cl}$.

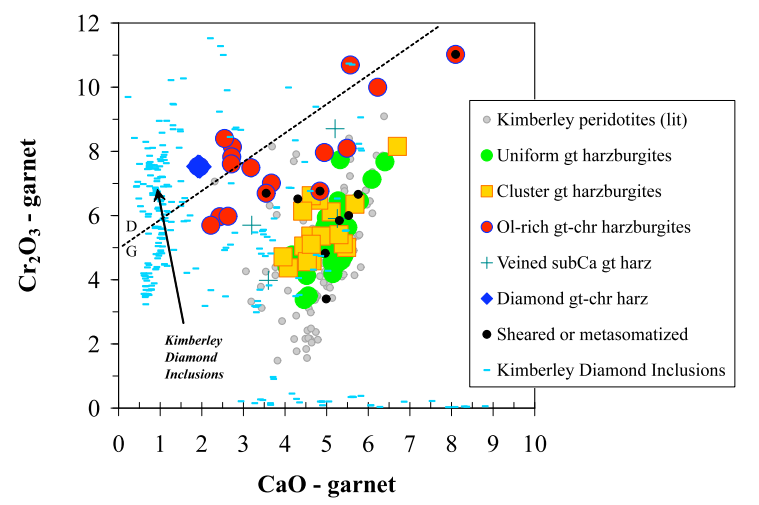

Fig. 1. Compositions of garnets from Kimberley xenoliths and diamond inclusions. Dashed line is the graphite-diamond constraint of Grütter et al. (2006) for a $38 \mathrm{mWm}^{-2}$ geotherm.

The two diamond-bearing garnet harzburgites contain the lowest $\mathrm{CaO}$ contents, whereas a metasomatized sample with realtively Ti-rich garnet $\left(0.44\right.$ wt. $\left.\% \mathrm{TiO}_{2}\right)$ and spinel (1.89 wt. \% $\left.\mathrm{TiO}_{2}\right)$ contains the most $\mathrm{Ca}$ and $\mathrm{Cr}$, and lies closest to the lherzolite array (Fig. 1).

The garnet compositions approach, but do not overlap substantially with those of Kimberley diamond inclusions (Phillips et al. 2004), which are generally 
poorer in $\mathrm{CaO}$ than the xenolith garnets. This suggests that the composition of the mantle has become more $\mathrm{CaO}$-rich since the garnets were encapsulated in diamond, as also inferred for xenoliths. The original compositional trend of extreme $\mathrm{CaO}$ depletion established by melting may be approximated by the dashed line in Fig. 2, demonstrating that the bulk of diamond inclusions were formed by higher degrees of melt extraction than currently recorded by xenoliths. However, $\mathrm{Ca} / \mathrm{Mg}$ and $\mathrm{Fe} / \mathrm{Mg}$ exchange between garnet and olivine during cooling from higher tempertures of diamond formation and melting could also account for some of the compositonal difference between garnets in xenoliths and diamond inclusions. About $150{ }^{\circ} \mathrm{C}$ of cooling is suggested by touching and non-touching inclusions (Phillips et al. 2004).

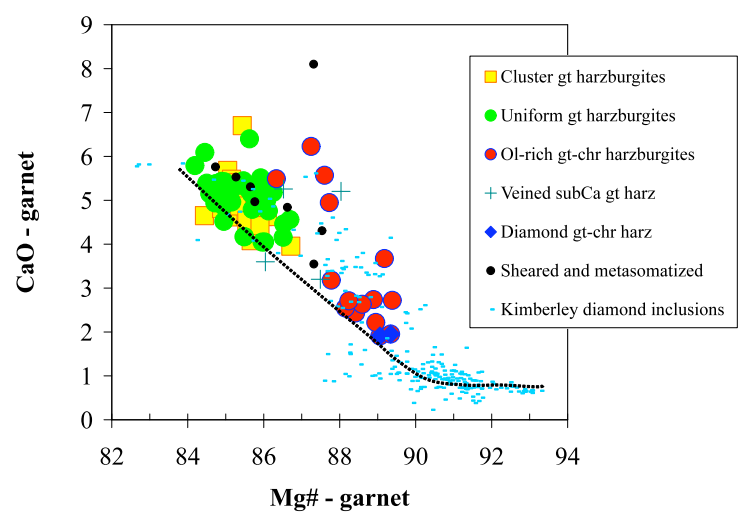

Fig. 2. $\mathrm{CaO}$ vs. $\mathrm{Mg}$ in garnet from Kimberley xenoliths (this study) and diamond inclusions (Phillips et al. 2004). Dashed line represents possible trend of melt depletion.

\section{Thermobarometry}

Olivine-rich peridotites are derived from pressures of $3.0-4.8 \mathrm{Gpa}$ within the mantle stratigraphic column at Kimberley using the O'Neill and Wood (1979, 1980) and Brey and Köhler (1990) thermobarometer combination (Fig. 3). The barometer of Grütter et al. (2006) places these samples at 2.7 - $4.5 \mathrm{GPa}$ for a 41 $\mathrm{mWm}^{-2}$ geotherm. The two diamond-bearing garnet peridotites lie close to the graphite-diamond curve and at the lowest range of pressures recorded by diamond inclusions from Kimberley.

Independent mineral barometers suggest that the olivine-rich depleted harzburgites extend throughout the range sampled by the xenolith suite at Kimberley. However, they form a high proportion of the total number of xenoliths recording pressures in excess of $4.5 \mathrm{GPa}$. The two diamond-bearing samples are among the deepest xenoliths recovered and overlap the range of diamond inclusions. There is, however, only limited depth overlap between xenoliths and the diamond inclusions which indicates derivation from greater pressures.

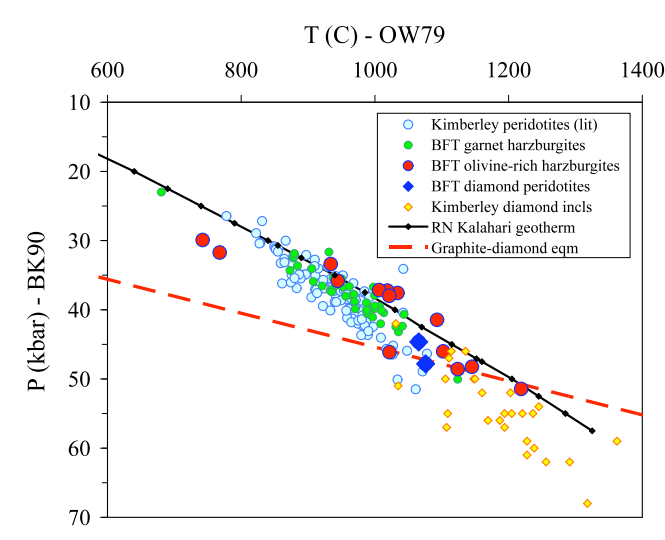

Fig. 3. PT conditions sampled by Kimberley xenoliths and diamonds. RN is the Rudnick-Nyblade Kalahari geotherm (Rudnick and Nyblade 1999). The PT estimates for Kimberley diamond inclusions were recalculated from the data of Phillips et al. (2004)

These observations lead to the following suggestions:

(1) diamond formation is associated with the formation of dunitic lithologies in the lithosphere

(2) the dunitic lithologies are distributed throughout the lithosphere, but are concentrated at its base, as has been suggested previously.

(3) dunite formation and diamond precipitation are cogenetic, i.e., depletion is accompanied by, rather than followed by, fluid infiltration.

\section{Bulk compositions}

Peridotite whole-rock compositions determined by XRF extend the range for Kaapvaal peridotites to extreme values of $\mathrm{Mg \#} \mathrm{(96)} \mathrm{and} \mathrm{Cr} \#$ (76). Relationships between $\mathrm{Cr}, \mathrm{Mg}, \mathrm{Fe}$ and $\mathrm{Si}$ indicate that Cr-rich spinel was present in the melting interval responsible for the Kimberley opx-poor harzburgite / dunite formation, contrasting with low-T cratonic harzburgites with $\mathrm{Mg}<93$ (Fig. 4).

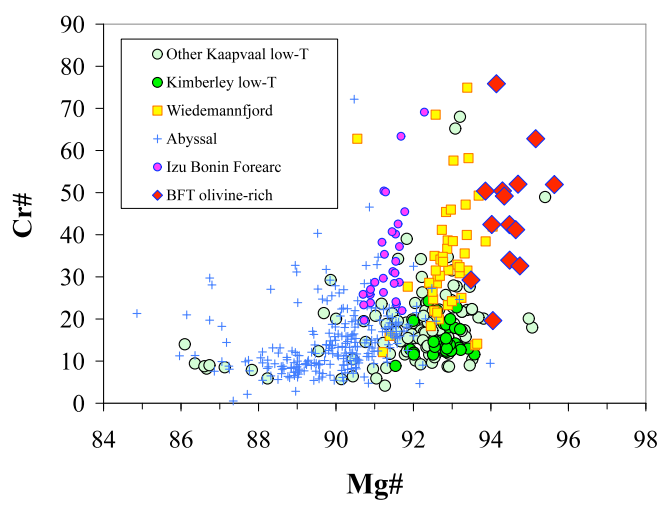

Fig. 4. Whole rock composition of Kimberley peridotites, compred with cratonic peridotites from Wiedemannfjord, Greenland (Bernstein et al. 1998), abyssal peridotites (PetDB database), and fore-arc seamonts from the Izu-Bonin arc (Parkinson and Pearce 1998). 
Similar trends are apparent in the data from the Izu-Bonin fore-arc and from the Wiedemannfjord xenoliths.

Whether spinel saturation indicates shallow melting is debatable and will be discussed. Removal of the spinel depth constraint permits the hypothesis that Archean mantle roots were not initially formed in subduction zones, though they were subsequently modified in such settings.

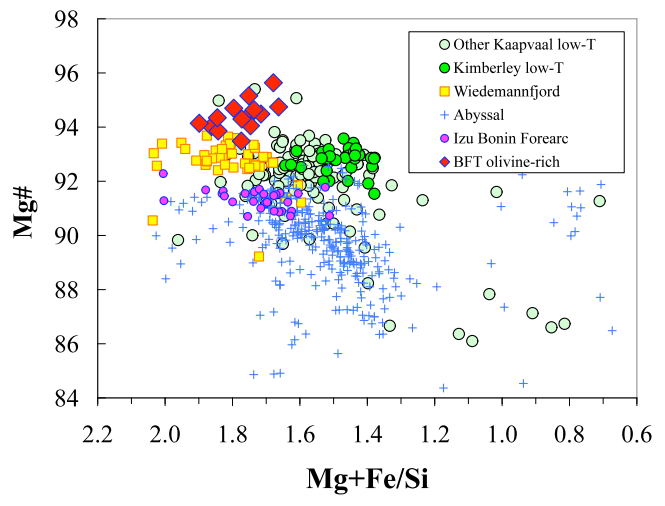

Fig. 5. $\mathrm{Mg \#}$ vs. Atomic $(\mathrm{Mg}+\mathrm{Fe}) / \mathrm{Si}$ for Kimberley and other peridotites. Data sources as for Fig. 4.

The trends defined by the Bultfontein olivine-rich harzburgite/dunite bulk compositions are not continuous with those of other refractory harzburgites from Kimberley, suggesting that they are not simply extreme melt residues. The dunites are anomalously depleted in $\mathrm{Fe}$ for their $\mathrm{Mg} / \mathrm{Si}$ ratios, displaying a trend of decreasing $\mathrm{Mg}+\mathrm{Fe} / \mathrm{Si}$ with increasing $\mathrm{Mg \#}$. This suggests a different melting reaction from that giving rise to other peridotites, and the involvement of volatiles. The presence of diamond and Cl-rich phlogopite, the high LIL concentrations in garnet, and the extreme depletion in HFSE and other magmaphile elements $(\mathrm{Ca}, \mathrm{Al})$ also point to involvement of fluids, rather than typical silicate melts, in the formation of the diamond-bearing duntitic rocks.

We suggest that the dunites are local features in subcratonic mantle analogous to the dunite melt channels in exposed peridotite massifs. A model of concomitant dunite formation and diamond precipitation by the fluxing and redox reaction of chloride-rich potassic, carbonate-bearing hydrous fluids will be presented. Brines derived either by direct dehydration of subducting lithosphere, or by the reaction-differentiation of siliceous slab-derived melts can play a major role in the chemical differentiation of Archean lithosphere.

\section{References.}

Bernstein, S., Kelemen, P. B., Brooks, C.K. 1998. Depleted spinel harzburgite xenoliths in Tertiary dykes from east Greenland: restites from high degree melting. Earth and Planetary Science Letters 154, 221-235.

Brey, G.P., Köhler, T. 1990. Geothermobarometry in four phase lherzolites II. New thermobarometers and practical assessment of existing thermobarometers. Journal of Petrology 31, 13531378.

Grütter, H. S., Latti, D. and Menzies, A. H. 2006. CrSaturation arrays in concentrate garnet compositions from kimberlite and their use in mantle barometry. Journal of Petrology 47, 801820.

O’Neill, H. S., Wood, B. J. 1979. An experimental study of $\mathrm{Fe}-\mathrm{Mg}$ partitioning between garnet and olivine and its calibration as a geothermometer. Contributions to Mineralogy and Petrology 70, 59-70.

Parkinson I. J. and Pearce, J. A. 1998. Peridotites from the Izu-Bonin-MarianaForearc (ODP Leg 125): Evidence for Mantle Melting and Melt-Mantle Interaction in a Supra-Subduction Zone Setting. Journal of Petrology 39, 1577-1618.

Phillips, D. et al. 2004. Proc. 8th Internat. Kimberlite Conference.

Pokhilenko, N. P., Sobolev, N. V., Boyd, F. R., Pearson, D. G., Shimizu, N., 1993. Megacrystalline pyrope peridotites in the lithosphere of the Siberian Platform; mineralogy, geochemical peculiarities and the problem of their origin, Russian Geology and Geophysics, 34, 5667.

Rudnick, R. L., Nyblade, A.A. 1999. The thickness and heat production of Archean lithosphere: constraints from xenolith thermobarometry and surface heat flow. In: Fei, Y., Bertka, C. and Mysen, B.O. (eds.) Mantle petrology: field observations and high-pressure experimentation: a tribute to Francis R. (Joe) Boyd. Geochemical Society Special Publication 6, 3-12. 